\title{
Cyanamide-Induced Hepatotoxicity and the Potential Protective Role of Pomegranate Seed Extract in Adult Male Albino Rats
}

\author{
Naema Mahmoud Elhosary, Doaa Mohamed Elgharbawy ${ }^{1}$, Amira A. Kassab ${ }^{2}$ and RM Elgharabawy ${ }^{3}$ \\ ${ }^{1}$ Department of Forensic Medicine and Clinical Toxicology, Faculty of Medicine. \\ 2 Department of Histology, Faculty of Medicine. \\ ${ }^{3}$ Department of Pharmacology and Toxicology, Faculty of Pharmacy. \\ Tanta University, Tanta, Egypt.
}

\begin{abstract}
Background: Dormex, which is used as agricultural fertilizer, contains cyanamide as an active ingredient. Pomegranate fruits enclose numerous polyphenols that guard normal cells against oxidative stress. Aim of the work: to study the hepatotoxic effects of Dormex and assess the protective capacity of pomegranate seed extract (PSE) in rats after 3 months of oral administration. Material \& methods: Sixty mature male albino rats were distributed to; Group I, II: rats were given $0.1 \mathrm{ml}$ distilled water/kg/day and $400 \mathrm{mg} / \mathrm{kg} /$ day of pomegranate seed extract (PSE), respectively. Group III: divided into two subgroups in which rats received $30 \& 60 \mathrm{mg} / \mathrm{kg} /$ day Dormex, respectively. Group IV: divided into two subgroups in which rats were given the same dose of Dormex plus PSE. Body and liver weights, serum albumin, total bilirubin and liver enzymes were assessed. Hepatic malondialdehyde (MDA), glutathione reductase and catalase activities were evaluated. Liver specimens were studied with H. \&E., Mallory's trichrome and caspase-3 immunostaining. Results: The hepatic index, liver enzymes, bilirubin, and MDA were significantly increased $(\mathrm{P}<0.001)$, while albumin, glutathione reductase, and catalase were lowered significantly in rats of experimental groups compared to the control $(\mathrm{P}<0.001)$. All these assessed parameters were within normal range in the protected groups. The histopathological changes included liver inflammation, degeneration and fibrosis, in addition to apoptosis. Treatment with PSE markedly prevented the occurrence of these abnormalities. Conclusion: Cyanamide prompts oxidative stress that compromises the liver function and eventually liver fibrosis results. These toxic effects are dose related. The PSE exhibits hepatoprotective effects and highlights the possibility of its use as a protective agent in individuals at high risk of Dormex toxicity.
\end{abstract}

\begin{tabular}{l|l} 
Keywords & Dormex; Cyanamide; Pomegranate; Oxidative stress; Liver enzymes; Histopathology
\end{tabular}

\section{Introduction}

A ccording to the latest WHO data published in May 2014 liver disease deaths in Egypt reached $8.92 \%$ of total deaths which contributed the third cause of death (World Health Rankings, 2014). Among the causes of liver diseases is environmental or occupational exposure to pollutants. Pesticides are considered one of the most common sources of pollutions. Different compounds such as insecticides, herbicides, fungicides, rodenticides, plant growth regulators and others are included under this group of term (Aktar et al., 2009).

Cyanamide is a chemical substance that was manufactured at the beginning twentieth century (Soltys et al., 2011).The calcium salt of hydrogen cyanamide $\left(\mathrm{CaCN}_{2}\right)$ is the active ingredient of Dormex, which is used as synthetic fertilizer in agriculture by spraying to facilitate the buds break (De Haro, 2009; Soltys et al., 2011). It is sold in a liquid formulation that is spread over the crops by nebulization with an atomizer (CDC, 2001).

Routes of exposure to Dormex are mainly respiratory, skin and gastrointestinal tract. Absorption is rapid from all routes. The mechanism of action of hydrogen cyanamide has not been verified accurately. It is partly converted to carbon dioxide which is exhaled or excreted in the feces, and the remainder is eliminated in the urine as $\mathrm{N}$-acetylcyanamide (Manoilov et al., 1996).

Despite, hydrogen cyanamide is rapidly broken down in the environment and is unlikely to persist as an environmental contaminant (Leung et al., 1993), there are adverse health effects have been documented from contact of hydrogen cyanamide including severe irritation and ulceration of the eyes, skin, and respiratory tract (CDC, 2005). 
However, the majority of reports on human toxic effects of Dormex were following occupational, accidental or suicidal exposures to the chemical. These reports have been pronounced from Italy, USA, India (Sheshadri et al., 2011).

Hepatotoxicity can be induced by free radical formation. Accordingly, the use of natural antioxidants is implemented as an approach to prevent oxidative damage related various organ disorders (Ben Amara et al., 2011). Therefore, medicinal plants have been considered a good, effective, inexpensive, safe, and available healthy source for the prevention of these disorders (Olaleye \& Rocha, 2008; Sen et al., 2011; Keter \& Mutiso, 2012).

Among these medicinal plants is pomegranate (Punica Granatum L., Punicaceae) fruit which has antiinflammatory (Costantini et al., 2014), anticancerous (Reddy et al., 2014), antiproliferative (Adams et al., 2010), antiatherogenic (Aviram et al., 2008), and radioprotective (Khan et al., 2012) properties.

Hence, limited studies on the toxic effect of Dormex are available in the database and its wide spread use in Egypt to augment crop productivity to suffice the increasing requirements of raised population. Therefore, the present study had been undertaken to investigate the hepatotoxic effects of Dormex and to assess the potential protective capacity of pomegranate seed extract on Dormex-induced liver injury in adult male albino rats.

\section{Materials and methods}

\section{Materials}

- Dormex (Hydrogen cyanamide 50\% w/w), produced by Ningxia Darong chemicals \& Metallurgy Co. LTD, China and purchased from Ind. Consult, Cairo, Egypt in the form of liquid (5 litres).

- Pomegranate seed extract (PSE) was obtained from pomegranate fruit (Punica granatum) which purchased from a local market in Tanta, Egypt.

Preparation of Pomegranate Seed Extract (PSE): Pomegranate juice was separated by pressuring the eatable portion of the fruit. Seeds were left to dry then they were crushed to fine powder. 100 gram of the powder was mixed with $300 \mathrm{ml}$ of $70 \%$ ethanol in distilled water and kept for 3 days at room temperature and then was filtered. Solvent (ethanol/water) was removed using a rotatory evaporator under vacuum at $50^{\circ} \mathrm{C}$. PSE obtained and kept in the refrigerator. Enough amount of the extract were suspended in water and given to animals of the protected group (Hemmati et al., 2013).

- All other chemicals that were used, were of high purity, and were obtained from EL-NASR, Pharmaceutical Chemicals Company, Cairo, Egypt.

\section{Animals}

Sixty adult male albino rats of similar age weighing $200 \pm 10 \mathrm{~g}$ were supplied by the animal house, Faculty of Medicine, Tanta University, Egypt. They were housed in stainless steel cages under standard conditions of temperature $\left(23 \pm 2{ }^{\circ} \mathrm{C}\right)$ in a $12 \mathrm{~h}$ light/dark cycles and a minimum relative humidity of $40 \%$. The free access of animals to food and drinking water were tolerated. According to the Guide for the Care and Use of Laboratory Animals, the animals of this study were treated (NRC, 1996). The study design was approved by the Research Ethics Committee of Tanta Faculty of Medicine.

\section{Experimental design}

After two weeks of laboratory accommodation, rats were randomly divided into four main groups as follows:

Group I (control): ten rats administered $0.1 \mathrm{ml}$ distilled water/kg/day as a vehicle for 3 months.

Group II (Pomegranate-treated group): ten rats were given $400 \mathrm{mg} / \mathrm{kg} /$ day of pomegranate seed extract (PSE) dissolved in sterile distilled water orally by gavage needle for 3 months (Hemmati et al., 2013).

Group III (Experimental groups): twenty rats divided equally into two subgroups; IIIA and IIIB in which $30\left(1 / 10 \mathrm{LD}_{50}\right)$ \& $60\left(1 / 5 \mathrm{LD}_{50}\right) \mathrm{mg} / \mathrm{kg} /$ day of Dormex dissolved in sterile distilled water were given orally to rats by gavage needle for 3 months, respectively. This duration is classified as a subchronic exposure according to Eaton and Klaassen (2001). Rat oral $\mathrm{LD}_{50}$ is $300 \mathrm{mg} / \mathrm{kg}$ according to Meister (1994).

Group IV (Protected groups): twenty rats divided equally into two subgroups; subgroup IVA and IVB in which rats were concomitantly given 30 \& 60 $\mathrm{mg} / \mathrm{kg} /$ day of Dormex dissolved in sterile distilled water plus PSE in the same dose as group II. These preparations were given orally by gavage needle for 3 months.

Methods

- The body weight of all rats was recorded on the first day before oral administration of chemicals then daily and the dose was adjusted accordingly. Lastly, the rats were weighted on the day of scarification. Twenty four hour after the last treatment, all animals were euthanized and a median abdominal incision was done where the liver was dissected immediately after bleeding and weighted.

- The data for hepatic index (relative weight of liver) was expressed as the ratio between the liver weight and body weight of the animals (Mukherjee et al., 2013):

Hepatic index (relative liver weight)

$=\underline{\text { Absolute liver weight (gm) X100 }}$

Final body weight (gm)

\section{Tissue preparation:}

Dissected liver was divided into two parts. The first portion was weighed and homogenized with a potterElvenhjem tissue homogenizer in phosphate buffer saline (PBS) $10 \mathrm{mM} \mathrm{pH} 7.4$ and centrifuged. The supernatant was used for determination of malondialdehyde (MDA) levels and glutathione reductase and catalase activities.

The second part was specimen from the upper part of the right lobe of the liver which was submerged 
directly in $10 \%$ neutral-buffered formalin. Then, the fixed specimens were washed, dehydrated and embedded in paraffin. Slices of five $\mu \mathrm{m}$ thickness were stained with haematoxylin and eosin (H\&E) (Bancroft \& Gamble, 2008) and Mallory's trichrome to assess the degree of collagen fibers deposition (Culling et al., 1985). Moreover, immunohistochemistry for caspase-3, were performed on formalin-fixed paraffin-embedded specimens.

For caspase- 3 immunohistochemistry: the sections were dewaxed, rehydrated, and incubated with phosphate buffered saline (PBS). Then, these sections were incubated overnight in a humid chamber with the primary antibody (rabbit anti-rat caspase-3 antibody) which was directed against the cleaved activated caspase-3. The sections were then washed three times in PBS and incubated with goat anti-rabbit peroxidase attached to secondary antibody (peroxidase-labelled streptavidine) for one hour and washed again three times in PBS. Immunoreactivity was visualized using 3, 3'diaminobenzidine (DAB)-hydrogen peroxide as a chromogen, and sections were counterstained with haematoxylin. The negative control sections were stained without exposure to primary antibody, while other steps of the procedure were the same (Huang et al., 2005).

\section{Biochemical assays:}

a. Blood samples were collected from the heart by direct cardiac puncture, and then were centrifuged at $1500 \mathrm{rpm}$ for 15 minutes at an ambient temperature, the isolated sera were stored at $20^{\circ} \mathrm{C}$ for biochemical assays to evaluate the liver function.

Serum alanine aminotransferase (ALT) and aspartate aminotransferase (AST) were determined spectrophotometrically at $340 \mathrm{~nm}$ according to Gella et al. (1985). Serum Alkaline phosphatase (ALP) was estimated according the method adopted by King and Armstrong (1934). Serum total bilirubin was determined by using colorimetric Diazo method at $578 \mathrm{~nm}$ according to Balistreri \& Shaw (1987). Serum Albumin was determined colorimetrically at $630 \mathrm{~nm}$ according to (Grant, 1987).

b. Protein content of liver homogenate was detected using Lowry et al. (1951) method. Then the oxidative stress parameters were assessed as follow:

- Estimation of MDA: the degree of lipid peroxidation in serum was determined by measurement of MDA at $534 \mathrm{~nm}$ using the thiobarbituric acid reactive substances (TBARS) method as illustrated by Ohkawa et al. (1979).

- Estimation of glutathione reductase activity: glutathione reductase assay (Goldberg and Spooner, 1983) was determined by measuring the rate of oxidation to $\mathrm{NADP}+$, which is associated by a decline in absorbance at $340 \mathrm{~nm}$ using commercial kit (Biodiagnostic, Cairo, Egypt).
- Determination of catalase activity (CAT): catalase activity was estimated spectrophotometrically at $240 \mathrm{~nm}$ by using Claiborne's method (1985).

Statistical and Morphometric analysis:

The collected data were organized and statistically analyzed using SPSS software statistical computer package for windows version 22. The distribution of quantitative data was evaluated using Shapiro-Wilkes test. Normally distributed data were expressed as mean and standard deviation. For comparison between the groups, either one way ANOVA or Welch ANOVA was used according to the results of Levene's test of homogeneity of variances. If significant differences were present, post hoc tests were performed (Tukey test after ANOVA and GamesHowell test after Welch ANOVA). Significance was assumed at $\mathrm{p}<0.05$ for interpretation of results (Dawson and Trapp, 2001).

The data were obtained using image analysis system (Leica Qwin 500 C image analyzer computer system, England) at National Research Center. The secondary antibody tagged cleaved caspase-3 subunit within the cytoplasm of hepatocytes was visualized. The optical density of the immunoreactions in the cells was measured in five non-overlapping fields from each liver specimen. In addition, the color area percentage of collagen fibers (blue colored) was measured in Mallory's trichrome stained slides at magnification of X400 in five non overlapping fields from each specimen.

\section{Results}

Evaluation of final body weight and hepatic index (Fig. 1 \& 2)

The final body weight of rats in experimental groups (IIIA, IIIB) was significantly decreased in comparison with both groups I\& II while, it was noticed that it was significantly higher in protected groups (IVA, IVB) than the experimental groups $(\mathrm{P}<0.05)$. On the other hand, rats of experimental groups showed significant increase of the hepatic index compared to the control group, while concomitant administration of PSE brought down the hepatic index of the protected rats as compared to the control group ( $p<0.05)$. Additionally, these changes were significantly dependent on the dose of Dormex as there were significant differences in body weight and hepatic index between subgroups IIIA and IIIB.

The effects of Dormex and pomegranate seed extract on liver function tests (Table 1):

Rats in group IIIA showed significant reduction in the level of serum albumin compared to the control and PSE treated groups $(\mathrm{P}<0.001)$, moreover it is much lower in group IIIB. However, this reduction in serum albumin was escalated significantly with simultaneous administration of both Dormex and PSE in groups IVA and IVB if compared to the control group $(\mathrm{P}<0.001)$.

The markers of hepatotoxicity; bilirubin, ALT, AST and ALP were elevated significantly in the 
experimental groups (group IIIB more than group IIIA) compared to the control group. On the contrary, rats of the protected groups revealed significant decline in these markers when matched with the experimental groups and the control group $(\mathrm{P}<0.001)$.

The effects of Dormex and pomegranate seed extract on oxidative stress parameters (Table 2):

The lipid peroxidation end product; MDA was significantly higher in the experimental groups than in the control and PSE treated groups. In the protected groups, levels of hepatic MDA were significantly diminished compared with that of the experimental groups $(\mathrm{P}<0.001)$. Meanwhile, the activities of hepatic glutathione reductase and catalase were lowered significantly in the experimental groups than in the control and PSE treated groups. In protected groups, both were increased efficiently $(\mathrm{P}<0.001)$.

The histopathological effects of Dormex and PSE on the liver:

\section{Haematoxylin and eosin stain}

Examination of H\&E stained sections of liver of control group (Group I) as well as pomegranate treated rats (Group II) revealed the normal histological architecture of classic hepatic lobules with the central vein creating their central axis. At their angles, there were portal areas containing connective tissue stroma and portal triad (Figs. 3a, b, c).

Liver sections of subgroup IIIA showed mild distortion of the normal hepatic architecture with mild dilatation and congestion of central veins and blood sinusoids as compared to control (Figs. 4a, b). The portal areas showed less dilatation and congestion of the portal veins with less cellular infiltration (Figs. 4 c, d). On the other hand, some hepatocytes showed cytoplasmic vacuolation with irregular outlines of their nuclei (Fig. 4e). Moreover, some sections showed localized foci of homogenous acidophilic hyalinized material with cellular infiltration (Fig. 4 f).

Examination of liver sections of subgroup IIIB showed severe histological changes as compared to the control group in the form of marked dilatation and congestion of the central veins and blood sinusoids (Figs.5a,b) and surrounded by cellular infiltration including mononuclear cells and fibroblast like cells (Fig.5a). In addition, the portal areas showed marked dilatation and congestion of the portal veins as well as bile duct proliferation, were surrounded by excessive cellular infiltration that included mononuclear cells and fibroblasts like cells (Fig. 5c).

The centrilobular hepatocytes showed markedly vacuolated cytoplasm, faint nuclei and discontinuous cell boundaries (Fig. 5d). There were areas of degenerated hepatocytes surrounded by cellular infiltration (Fig. 5e). Furthermore, some hepatocytes were replaced by an area of homogenous acidophilic hyalinized material surrounded by cellular infiltration (Fig. 5f).

Liver sections of rats in subgroups IVA and IVB showed apparently more or less normal hepatic architecture similar to the control group (Figs.6a, b, c, d).

\section{Mallory's trichrome stain}

Liver sections of group I as well as Group II revealed very thin layer of collagen fibers around the central veins and the elements of portal tracts (Fig.7a,b).

In subgroup IIIA, the liver sections showed deposition of moderate amount of collagen fibers around the central veins and the portal areas (Fig. 7c, d), while subgroup IIIB, showed deposition of marked amount of collagen fibers around and in-between the central veins and around the portal tracts (Fig. 8a, b, c).

Concerning subgroups IVA\&IVB, the sections showed deposition of few fine collagen fibers around the central veins and the portal tracts (Figs. 9a, b, c, d).

\section{Immunohistochemical results}

Examination of caspase-3 immunostained sections of liver from the group I and group II affirmed that caspase-3 immunoreactivity was rarely detected (Fig. 10a).

In subgroup IIIA showed moderate caspase-3 immunoreaction in some cells (Fig. 10b), while subgroup IIIB, caspase-3 immunostained sections showed strong reaction in many cells where caspase-3 immunoreaction was detected in the cytoplasm of hepatocytes (Fig. 10c). However in subgroups IVA \&IVB, weakcaspase-3 immunoreaction was detected in few cells (Figs. 11a, b).

\section{Morphometric and statistical results}

Quantitative assessment indicated a statistically non significant difference $(\mathrm{P}>0.05)$ regarding the mean color area percentage of collagen fibers and the mean optical density of cytoplasmic immunoreaction of caspase-3 in group II compared to control group I. In experimental groups, there was a significant increase $[\mathrm{P}<0.05]$ in the mean color area percentage of collagen fibers and in the mean optical density for cytoplasmic immunoreactions of caspase-3 compared with control specimens. However, there was no statistically significant difference between the protected groups and control group (Tables $3 \& 4$ ). 
Table (1): Comparison of Liver function tests between the studied groups

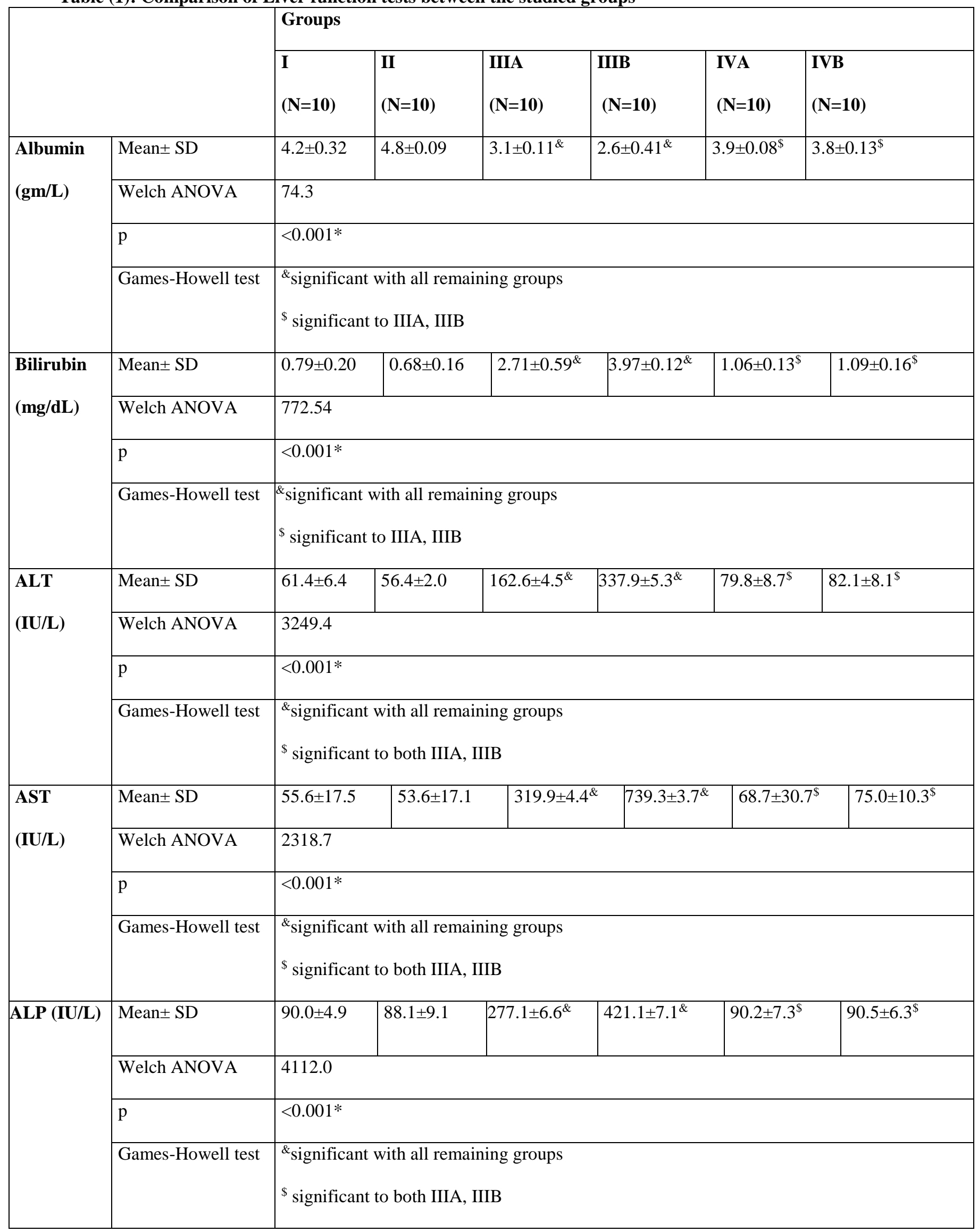

N: number; SD: standard deviation; * significant at $p<0.05$; superscript symbols refer to the groups compared. 
Table (2): Comparison of malondialdehyde, reduced glutathione and catalase activity between the studied groups

\begin{tabular}{|c|c|c|c|c|c|c|c|}
\hline & & Groups & & & & & \\
\hline & & $\begin{array}{l}I \\
(N=10)\end{array}$ & $\begin{array}{l}\text { II } \\
(N=10)\end{array}$ & $\begin{array}{l}\text { IIIA } \\
(\mathrm{N}=\mathbf{1 0})\end{array}$ & $\begin{array}{l}\text { IIIB } \\
(\mathrm{N}=10)\end{array}$ & $\begin{array}{l}\text { IVA } \\
(\mathrm{N}=10)\end{array}$ & $\begin{array}{l}\text { IVB } \\
(N=10)\end{array}$ \\
\hline Malondialdehyde & Mean \pm SD & $62.8 \pm 12.7$ & $45.6 \pm 6.5$ & $88.6 \pm 11.9^{\&}$ & $99.9 \pm 7.8^{\&}$ & $47.8 \pm 7.6^{\$}$ & $52.4 \pm 7.4^{\$}$ \\
\hline$(\mu \mathrm{M} / \mathrm{mg})$ & One way ANOVA & 46.6 & & & & & \\
\hline & $\mathrm{P}$ & $<0.001^{*}$ & & & & & \\
\hline & Tukey test & $\begin{array}{l}{ }^{\&} \text { significan } \\
\$ \text { significan }\end{array}$ & $\begin{array}{l}\text { with all ren } \\
\text { to both III }\end{array}$ & $\begin{array}{l}\text { naining group } \\
\text { A, IIIB }\end{array}$ & but not to e & each other & \\
\hline $\begin{array}{l}\text { Reduced Glutathione } \\
\text { Activity }\end{array}$ & Mean \pm SD & $\begin{array}{l}13638.8 \\
\pm 865.7\end{array}$ & $\begin{array}{l}13799.9 \\
\pm 1469.9\end{array}$ & $\begin{array}{l}11657.8 \\
\pm 1251.3^{\&}\end{array}$ & $\begin{array}{l}10139.7 \\
\pm 2875.3^{\&}\end{array}$ & $\begin{array}{l}12974.5 \\
\pm 697.3^{\$}\end{array}$ & $\begin{array}{l}12888.3 \pm 1 \\
029.9^{\$}\end{array}$ \\
\hline & One way ANOVA & 7.8 & & & & & \\
\hline & $\mathrm{P}$ & $0.001^{*}$ & & & & & \\
\hline & Tukey test & $\begin{array}{l}{ }^{{ } \text {significan }} \\
\$ \text { significan }\end{array}$ & $\begin{array}{l}\text { with all rer } \\
\text { to both III }\end{array}$ & $\begin{array}{l}\text { naining group } \\
\text { A, IIIB }\end{array}$ & s but not to $\epsilon$ & each other & \\
\hline $\begin{array}{l}\text { Catalase Activity } \\
(\mu \mathrm{M} / \mathrm{min} / \mathrm{mg})\end{array}$ & Mean \pm SD & $\begin{array}{r}205.5 \\
\pm 38.1\end{array}$ & $\begin{array}{l}210.6 \\
\pm 32.8\end{array}$ & $\begin{array}{l}105.3 \\
\pm 20.9^{\&}\end{array}$ & $\begin{array}{l}101.7 \\
\pm 15.6^{\&}\end{array}$ & $\begin{array}{l}191.2 \\
\pm 46.8^{\$}\end{array}$ & $\begin{array}{l}177.6 \\
\pm 35.2^{\$}\end{array}$ \\
\hline & One way ANOVA & 28.4 & & & & & \\
\hline & $\mathrm{P}$ & $0.001 *$ & & & & & \\
\hline & Tukey test & $\begin{array}{l}{ }^{\&_{\text {significan }}} \\
\$ \text { significan }\end{array}$ & $\begin{array}{l}\text { with all rer } \\
\text { to both III }\end{array}$ & $\begin{array}{l}\text { naining group } \\
\text { A, IIIB }\end{array}$ & s but not to $\epsilon$ & each other & \\
\hline
\end{tabular}

N: number; SD: standard deviation; * significant at $p<0.05$; superscript ${ }^{\&}$ and ${ }^{\$}$ refer to the groups compared.

Table (3): The mean color area percentage of collagen fibers stained by Mallory's trichrome in different groups

\begin{tabular}{|l|c|}
\hline Groups & $\begin{array}{l}\text { Color area percentage of collagen } \\
\text { fibers (Mean } \pm \text { SD) }\end{array}$ \\
\hline I & $0.05 \pm 0.02$ \\
\hline II & $0.04 \pm 0.009$ \\
\hline IIIA & $0.119 \pm 0.046^{*}$ \\
\hline IIIB & $0.14 \pm 0.06^{*}$ \\
\hline IVA & $0.07 \pm 0.03$ \\
\hline IVB & $0.08 \pm 0.018$ \\
\hline
\end{tabular}

$\left({ }^{*}\right)$ : significant compared with control animals at $p<0.05$; SD: Standard deviation 
Table (4): The optical density of caspase-3 immunoreaction in different groups

\begin{tabular}{|l|l|}
\hline Groups & $\begin{array}{l}\text { Optical density } \\
{[\text { Mean } \pm \text { SD] }}\end{array}$ \\
\hline I & $7.82 \pm 1.53$ \\
\hline II & $7.80 \pm 1.50$ \\
\hline IIIA & $25.10 \pm 4.53^{*}$ \\
\hline IIIB & $36.77 \pm 8.60 *$ \\
\hline IVA & $8.21 \pm 1.03$ \\
\hline IVB & $9.19 \pm 1.44$ \\
\hline
\end{tabular}

(*): significance compared with control animals at $p<0.05$; SD: Standard deviation

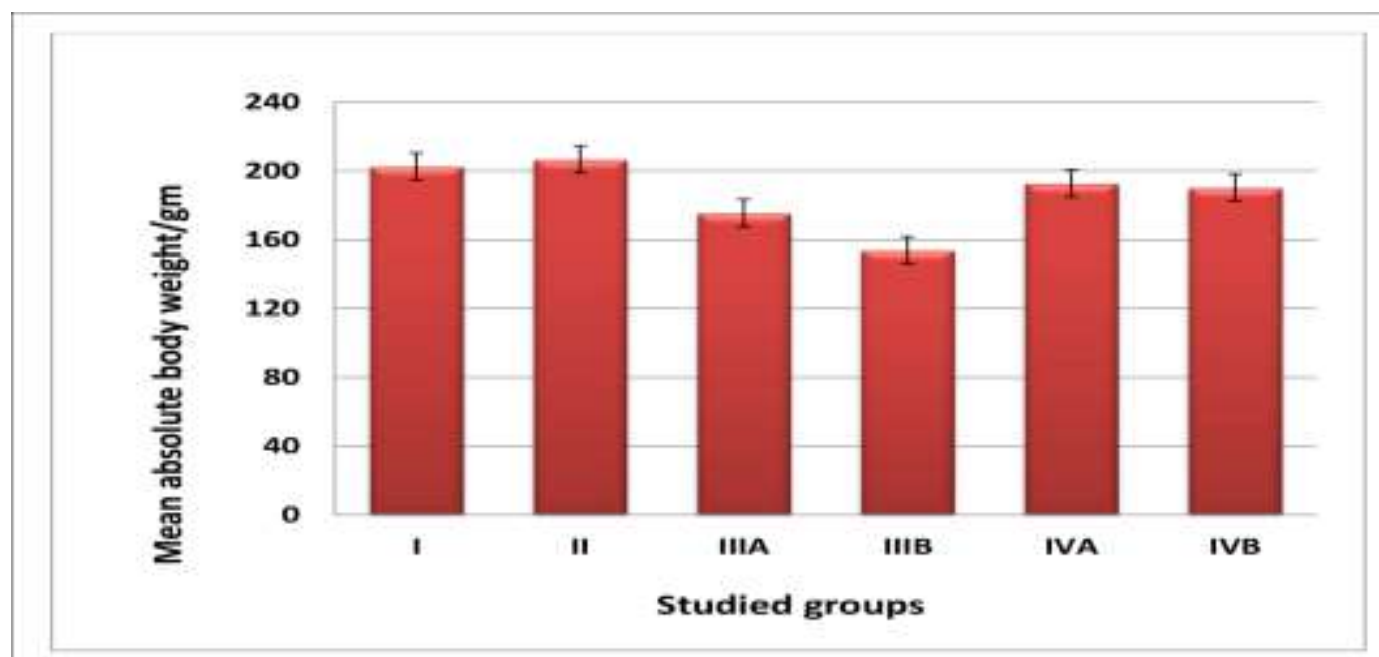

Fig. 1: Mean of absolute body weight in the studied groups $(+/-1$ SD).

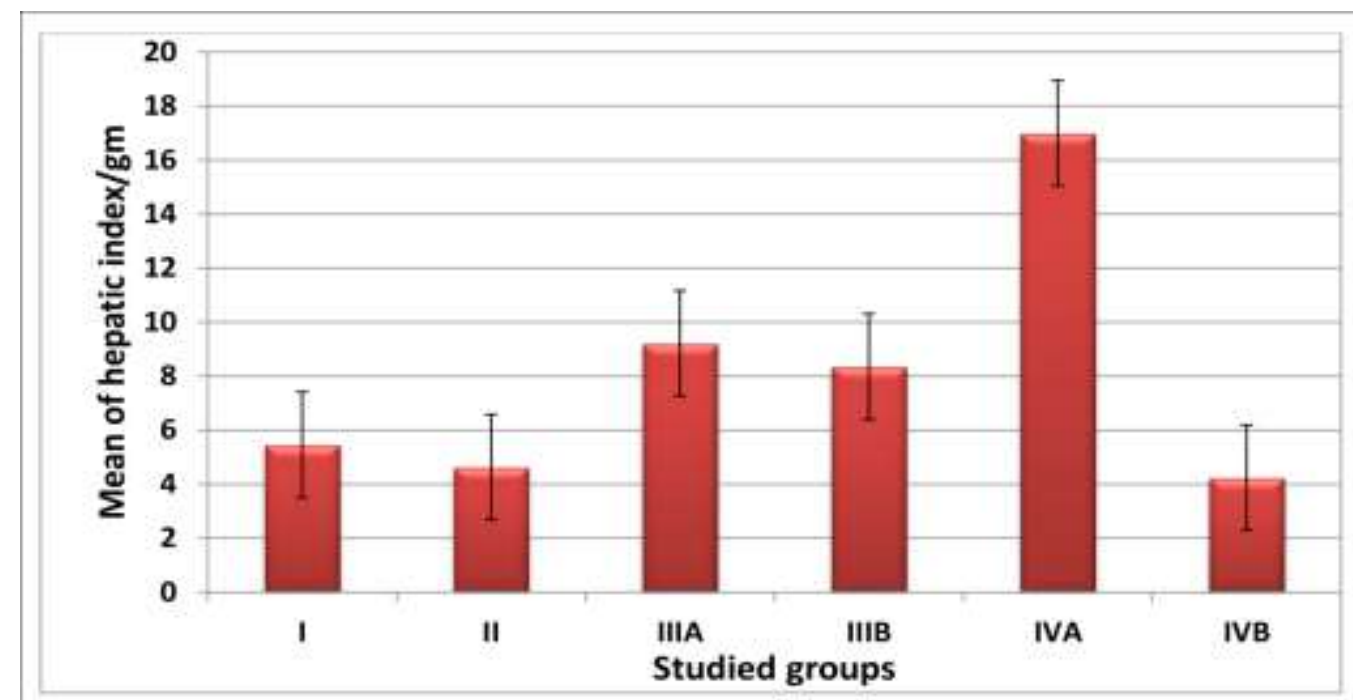

Fig. 2: Mean of hepatic index in the studied groups $(+/-1$ SD).

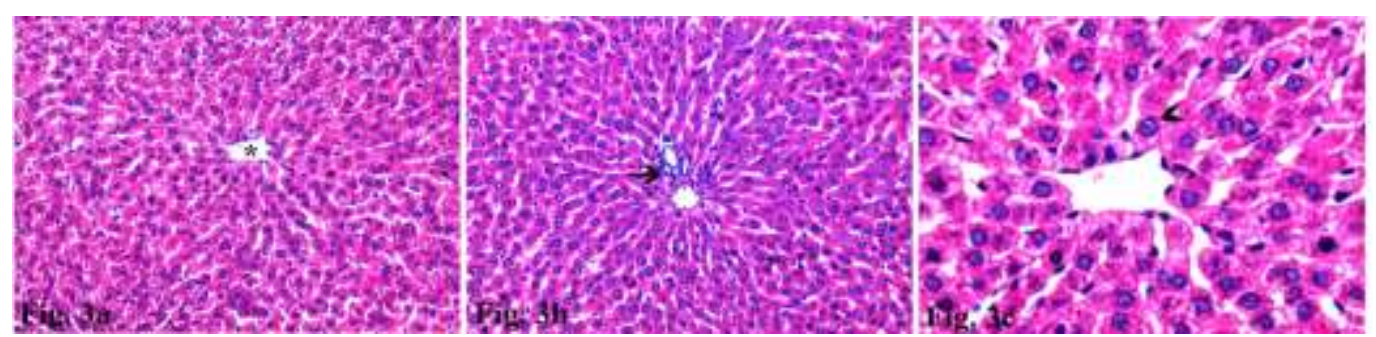

Fig. 3a, b: Showing normal hepatic lobular architecture with central vein at the center $(*)$ and portal tract at the periphery $(\rightarrow)$ (control group, H. \&E. x400). Fig. 3c: A higher magnification showing cords of polyhedral hepatocytes ( $)$ with large rounded vesicular nuclei separated by the blood sinusoids (control group, H.\&E.x1000) 


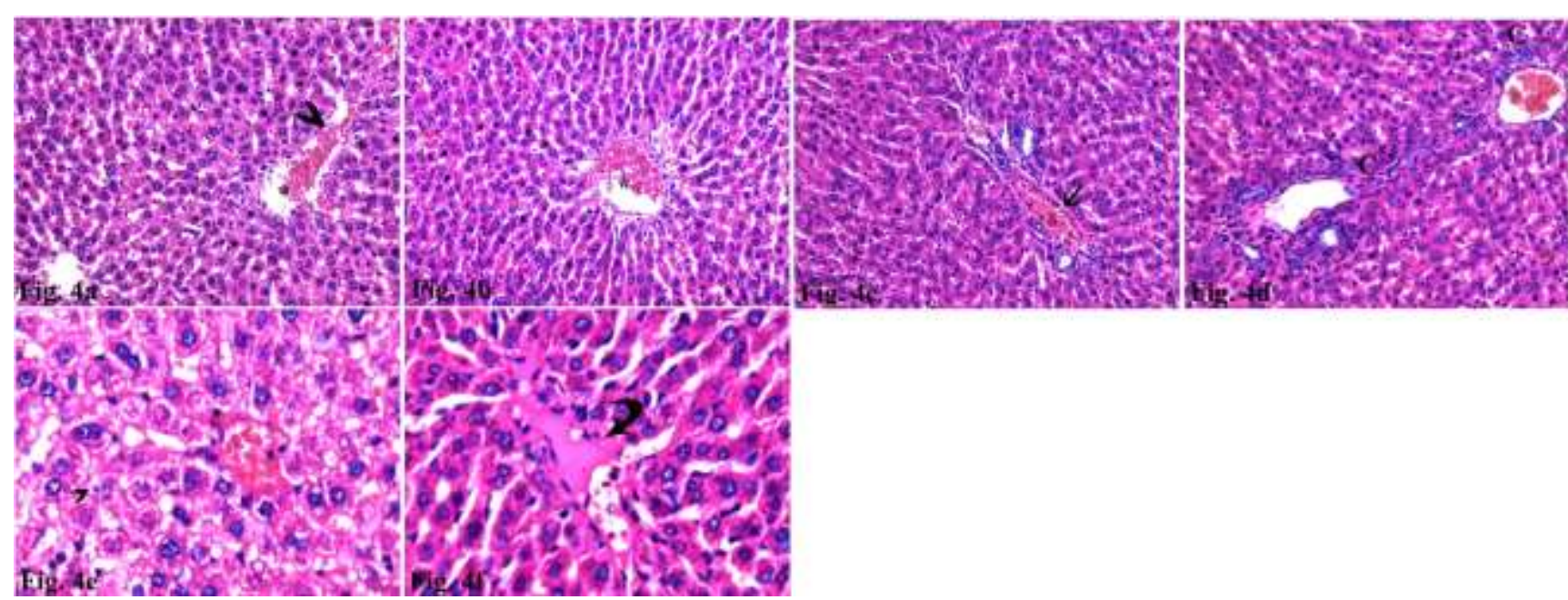

Fig. 4a, b: Showing mild dilatation and congestion of central vein $(*)$ and blood sinusoid ( $($ ) (Subgroup IIIA, H. \&E. x 400). Fig. 4c: Showing dilatation and congestion of portal vein $(\rightarrow)$. Fig. 4d: Showing cellular infiltration of portal area (C) (Subgroup IIIA, H. \&E. X400). Fig. 4e: Showing centrilobular hepatocytes with vacuolated cytoplasm and irregular outlines of their nuclei (1). Fig. 4f: Showing localized focus of homogenous acidophilic hyalinized material with cellular infiltration (curved arrow) (Subgroup IIIA, H. \&E. $\mathbf{x 1 0 0 0 )}$.
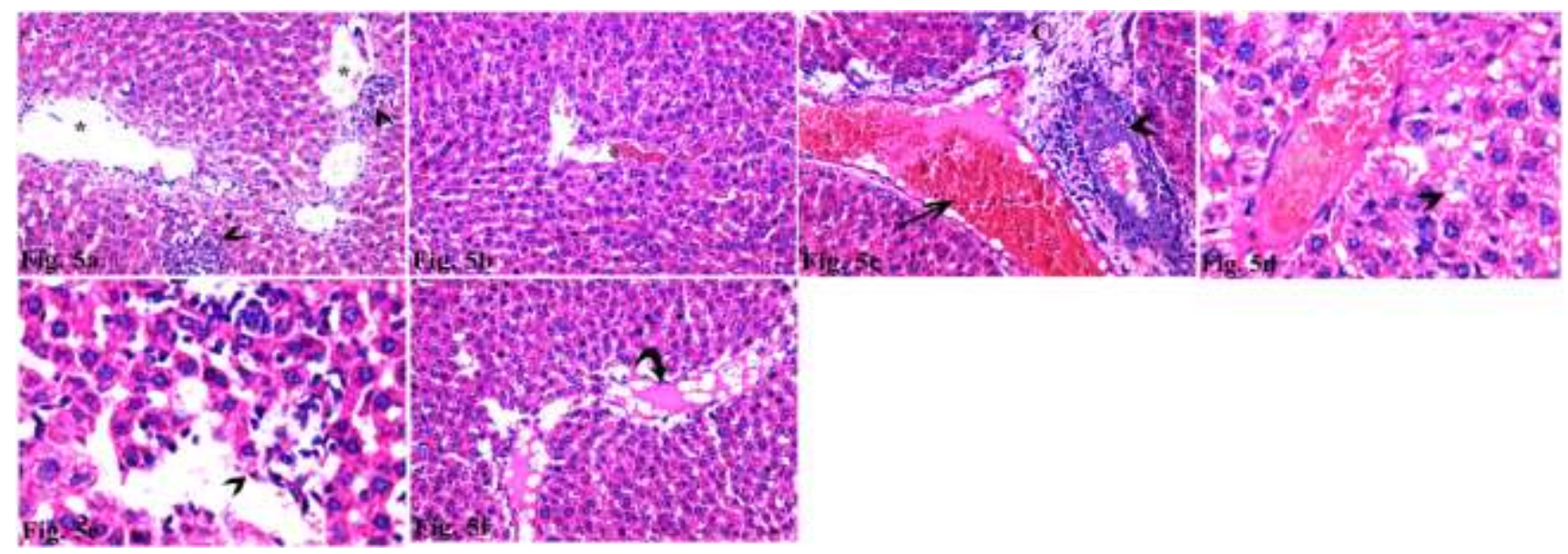

Fig. 5a, b: Showing distorted hepatic lobular architecture, marked dilatation and congestion of the central veins and blood sinusoids $(*)$ in addition to cellular infiltration ()) (subgroup IIIB, H. \&E. X400). Fig.5c: showing marked dilatation and congestion of portal vein $(\rightarrow)$, excessive cellular infiltration (C) in portal area as well as proliferation of bile ducts( $>$ ) (Subgroup IIIB, H. \&E. X400). Fig. 5d: Showing centrilobular hepatocytes with markedly vacuolated cytoplasm and faint nuclei ()). Fig.5e: showing degenerated hepatocytes surrounded by cellular infiltration()) (Subgroup IIIB, H. \&E.x1000). Fig. 5f: showing area of homogenous acidophilic hyalinized material surrounded by cellular infiltration(curved arrow) (Subgroup IIIB, H. \&E.x400).
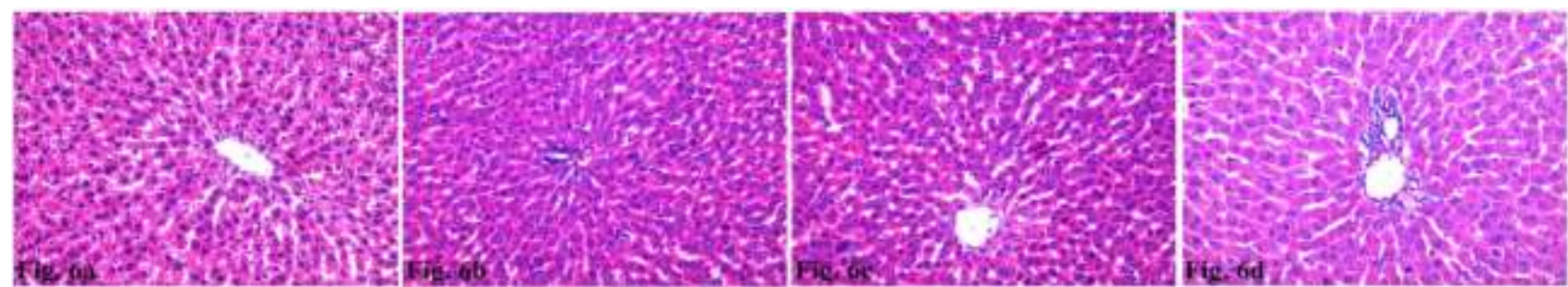

Fig. 6a, b: Showing apparently normal hepatic lobular architecture (Subgroup IVA, H. \&E. x400). Fig. 6c, d: Showing apparently normal hepatic lobular architecture (Subgroup IVB, H. \&E. x400). 


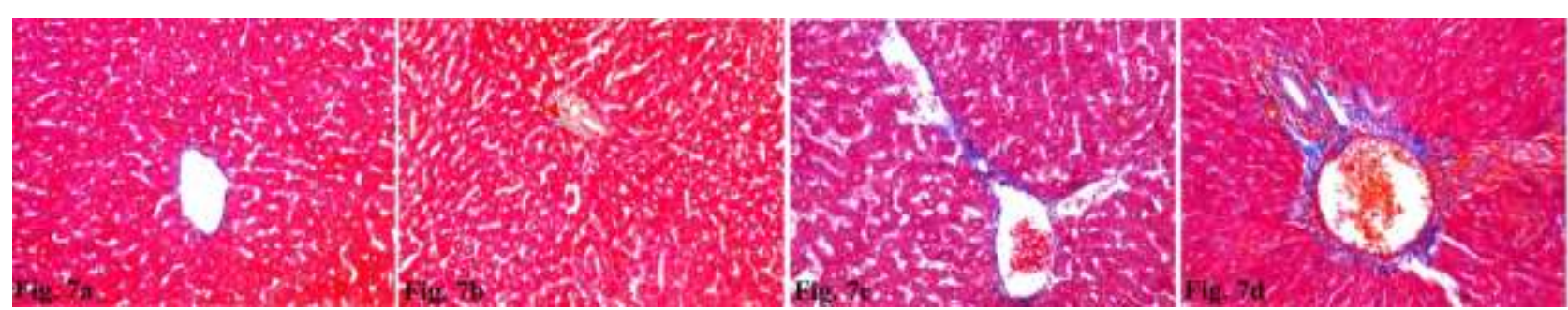

Fig. 7a, b: Showing normal distribution of very thin layer of collagen fibers around central vein and elements of portal tract (control group, Mallory's trichrome X400). Fig. 7 c, d: Showing deposition of moderate amount of collagen fibers in the wall of dilated central vein, dilated blood sinusoids and around elements of portal tract (Subgroup IIIA, Mallory's trichrome x400).
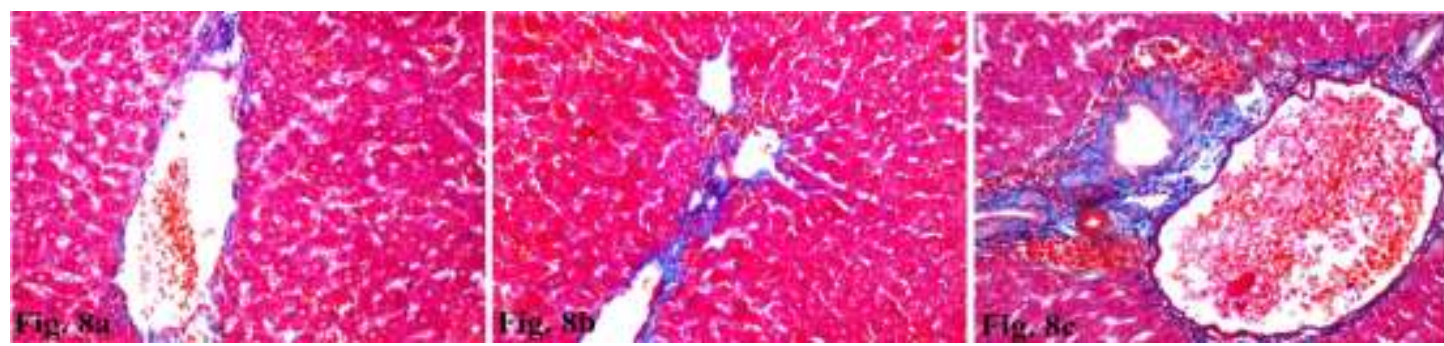

Fig. 8a,c: Showing deposition of marked amount of collagen fibers in the wall of dilated central vein and around elements of portal tract. Fig.8b: Showing thick bundles of collagen fibers extending between the central veins(Subgroup IIIB,Mallory'strichrome x400).
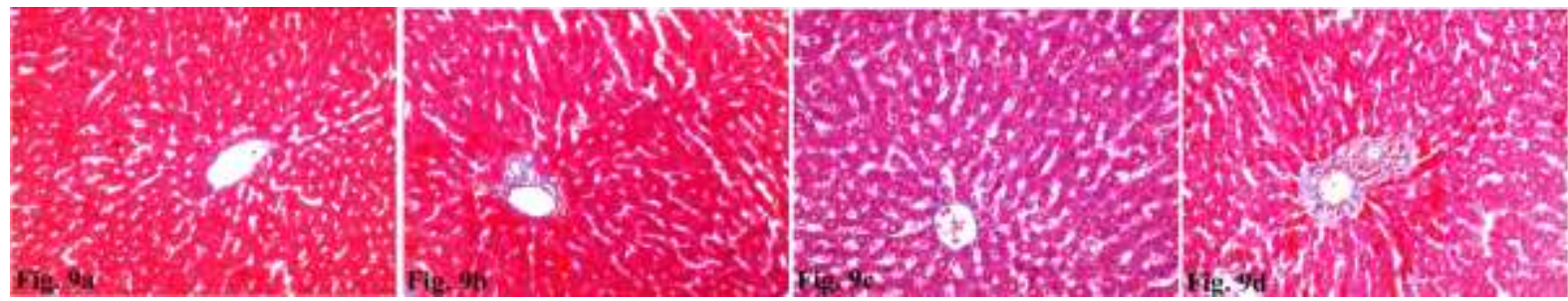

Fig. 9a, b, c, d: Showing deposition of few fine collagen fibers around central veins and around elements of portal tract (Subgroup IVA 'a, b' and Subgroup IVB 'c, d', Mallory's trichrome x400).
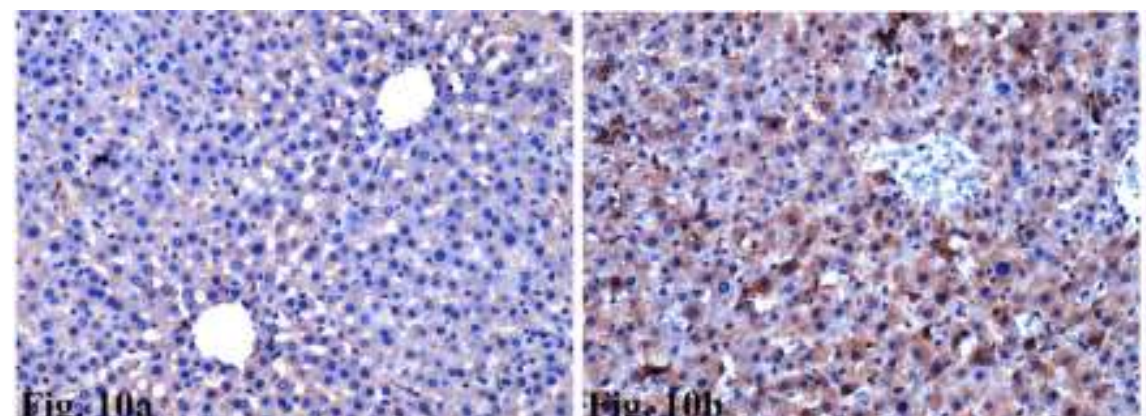

Fig 10a: Showing normal structure with no caspase-3 positive cells. (Control group, Caspase-3 immunostaining \& Hematoxylin counterstain x400). Fig 10b: Showing moderate cytoplasmic immunoreaction of caspase-3 in some hepatocytes (Subgroup IIIA, Caspase-3 immunostaining \& Hematoxylin counterstain $\times 400$ ). Fig 10c: Showing strong cytoplasmic immunoreaction of caspase-3 in many hepatocytes (Subgroup III B, Caspase-3 immunostaining \& Hematoxylin counterstain $\times 400$ ). 


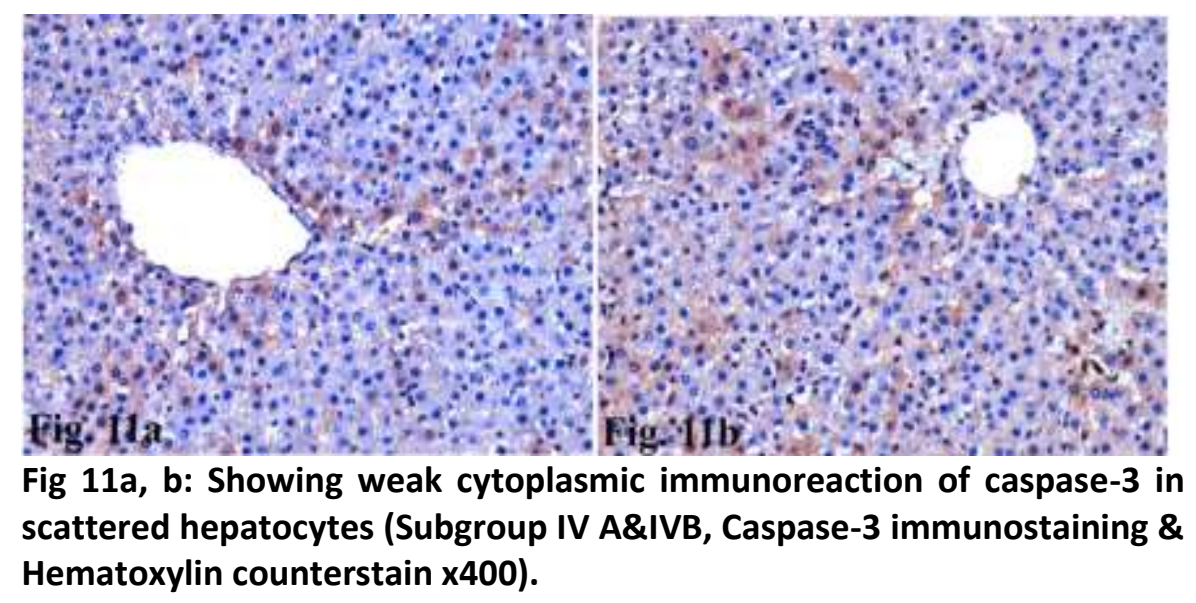

\section{Discussion}

The current study was designed to study the hepatotoxic effects of Dormex following sub-chronic exposure in adult male albino rats and the possible protective role of concomitant administration of PSE.

In the present study, Dormex administration to rats caused a significant reduction of body weight in contrast; the relative liver weight was increased significantly that indicated diminished liver functional ability. These changes were markedly improved as a result of co-administration of Dormex with PSE. These findings were close to the results of Mukherjee et al. (2013) study that was carried out to delineate the degree of methotrexate induced damage in the liver cells and its recovery by co-treatment with pomegranate fruit extract. The increased hepatic index may be attributed to the pathological changes which included congestion of central veins and infiltration of the hepatic lobule with inflammatory cells and deposition of hyalinized materials as observed in H. \& E. liver specimens.

Ingestion of Dormex in experimental rats caused significant elevation of the serum levels of liver enzymes; ALT, AST, ALP, and bilirubin in addition to marked reduction in serum albumin. However, the cotreatment with PSE derived significant improvement of all measured parameters in the protected groups. The ALT, AST enzymes are hepatospecific markers of injury. They are found within the cytosol of the hepatocytes and a rise in their serum activities is an evidence of their escape from the cell due to alteration of cell membrane permeability, hence hepatocyte injury is ensured (Rosen and Keeffe, 2000). The Increased total serum bilirubin was mainly of the direct type, it was produced as a result of hepatic cell damage and intrahepatic biliary cholestasis which was evidenced by high ALP level as it is a marker of hepatobiliary dysfunction (Saxena and Sharma, 2015).
The reduction in serum albumin could be ascribed to alterations in the metabolism and synthesis of protein and amino acids in the liver in addition to increased proteolytic activity or degradation (Yeragi et al., 2003). Takeo (1987) highlighted that the binding affinity of human albumin with xenobiotics and alkylating agents is high. Moreover, the observed decrease in serum albumin could be partially attributed to the damaging effect of Dormex on liver cells, as proved by the increase in serum activities of AST and ALT.

In the current study, the oxidative stress parameters in experimental rats exhibited significant elevation of MDA whereas, the opposing antioxidants; glutathione reductase and catalase were significantly diminished. PSE administration showed effective antioxygenation in Pomegranate-treated group as well as the protected groups as marked improvement of these markers was ensued.

Parmar and Kar (2007) stated that ingestion of pomegranate peel extract significantly decreased the tissue (hepatic, renal, and cardiac) and serum malondialdehyde as compared to the parallel values of atherogenic diet-fed animals. Oxidation of membrane polyunsaturated fatty acid resulted in its destruction and the production of MDA compound (oxidative stress marker in the body) which causes cell injury and chronic liver injury thereby fibrosis (Wasser and Tan, 1999)

Accordingly, these changes can be explained based upon the supposed mechanism of Dormex action which entailed inhibition of catalase resulting in uncoupling of oxidative phosphorylation and inhibition of adenosine nucleotide synthesis (Manoilov et al., 1996). Cyanamide is considered as an aldehyde dehydrogenase inhibitor that can produce disulfiramlike syndromeand depletion of the glutathione content 
of the hepatocytes (Hammond and Fry, 1999 \& Koppaka et al., 2012). It also impaired MDA, acetaldehyde, and hexanal metabolism reflecting oxidative damage induced by this compound (De Zwart et al., 1999).

It is therefore assumed that these toxicities could be lessened by using antioxidants (Mukherjee et al., 2013). The pomegranate fruit is an important natural source of potent antioxidants due to its high polyphenolic content, specifically anthocyanins, hydrolysable tannins and condensed tannins. Polyphenolics, have powerful free radicals scavenging and antioxidant properties, so hepatoprotection against chemically induced liver injury was achieved in rodents (Gil et al., 2000 \& Celik et al., 2009). The interaction of pomegranate fibers with Dormex inhibits its intestinal absorption which is another supposed mechanism of pomegranate inhibited Dormex toxicity. It has been advised to supplement the diets with pomegranate as it may prevent DNA damage (AlJarallah et al., 2013).

Microscopic examinations of H\&E liver sections from the experimental groups revealed degeneration, inflammation and fibrosis. While the H\&E liver sections from the protected groups illustrated more or less normal hepatic architecture indicating that the co-treatment of rats with PSE and Dormex protected the liver from the injurious effect of the Dormex. These changes were confirmed by the caspase-3 immuno-histochemistry which declared that there was an element of apoptosis that mediated the tissue injury. Mallory's trichrome stains explored Dormex induced liver fibrosis due to deposition of collagen fibers and the protective effect of administration of PSE as anti-fibrotic agent.

The study of Wei et al. (2015) showed similar results as the current study, that treatment with the extracts of pomegranate peels and seeds seemed to be useful in the animal model of carbon tetrachloride injury in terms of decreased hepatic and spleen index, amended liver function, and prohibited the development of liver fibrosis in rats.

\section{Conclusion}

This study elucidated that the Dormex increases the hepatic index, impairs the liver function. It induces oxidative stress as evidenced by the elevation of MDA and the marked decline in the antioxidants enzymes glutathione reductase and catalase. Liver inflammation, degeneration and fibrosis are observed. These toxic effects are dose dependent. They may be attributed to cyanamide induced oxidative stress. The administration of PSE ameliorates these abnormalities because it inhibits the oxidative stress, stimulates production of antioxidant enzymes and exerts anti-inflammatory effects thereby decreasing apoptosis and resultant liver fibrosis. So, PSE has hepatoprotective effects that highlight the possibility of using it as a protective agent in individuals at high risk of Dormex toxicity.

\section{Acknowledgement}

The authors would like to thank all staff members and technicians of Forensic Medicine and Clinical Toxicology department, Faculty of Medicine, Tanta University, Egypt for their assistance in finishing this study.

\section{References}

Adams LS, Zhang Y, Seeram NP et al. (2010): Pomegranate ellagitannin derived compounds exhibit antiproliferative and antiaromatase activity in breast cancer cells in vitro. Cancer Prev. Res. (Phila). 3 (1):108-113.

Aktar MW, Sengupta D and Chowdhury A (2009): Impact of pesticides use in agriculture: their benefits and hazards. Inter discip Toxicol. 2(1):1-12.

Al-Jarallah A, Igdoura F, Zhang Y et al. (2013): The effect of pomegranate extract on coronary artery atherosclerosis in SR-BI/APOE double knockout mice. Atherosclerosis. 228(1):80-89.

Aviram M, Volkova N, Coleman R et al. (2008): Pomegranate phenolics from the peels, arils, and flowers are antiatherogenic: studies in vivo in atherosclerotic apolipoprotein edeficient (E 0) mice and in vitro in cultured macrophages and lipoproteins. J. Agric. Food Chem. 56(3):1148-1157.

Balistreri WR and Shaw LM (1987): Liver function. In: Fundamentals of Clinical Chemistry, Tietz NW (ed), $3^{\text {rd }}$ ed., W.B. Sanders Company, Philadelphia USA, pp. 729 - 761.

Bancroft JD and Gamble M (2008): Theory and practice of histological techniques, $6^{\text {th }} \mathrm{ed}$., Churchill Living stone: Elsevier Health Science. Philadelphia USA, pp. 121 - 134.

Ben Amara I, Soudani N, Troudi A et al. (2011): Antioxidant effect of vitamin $\mathrm{E}$ and selenium on hepatotoxicity induced by dimethoate in female adult rats. Ecotoxicol. Environ. Saf. 74(4):811-819. 
Celik I, Temur A and Isik I (2009): Hepatoprotective role and antioxidant capacity of pomegranate (Punicagranatum) flowers infusion against trichloroacetic acid-exposed in rats. Food Chem. Toxicol. 47(1): 145-149

Centers for Disease Control and Prevention (CDC) (2001): Pesticide-related illnesses associated with the use of a plant growth regulator-Italy, MMWR Morb. Mortal. Wkly. Rep. 50(39):845-847.

Centers for Disease Control and Prevention (CDC) (2005): Update: Hydrogen Cyanamide-Related Illnesses- Italy, 2002-2004. MMWR Morb.Mortal. Wkly. Rep. 54(16):405-408.

Claiborne A (1985): Catalase activity. In: Handbook of methods for oxygen radical research, Greenwald RA (ed). CRC Press, Boca Raton, pp. 283-284.

Costantini S, Rusolo F, De Vito V et al. (2014): Potential anti-Inflammatory effects of the hydrophilic fraction of pomegranate (Punicagranatum L.) seed oil on breast cancer cell lines. Molecules. 19(6): 86448660.

Culling CFA, Allison RT and Barr WT (1985): Cellular pathology technique, $4^{\text {th }}$ ed., MidCounty Press, London, pp. 164-180.

Dawson B and Trapp RG (2001): Basic and clinical biostatistics, $3^{\text {rd }}$ ed, Lang Medical BookMcGraw-Hill, New York, pp. 161-218.

De Haro L (2009): Disulfiram-like syndrome after hydrogencyanamide professional skin exposure: two case reports in France. J. Agromedicine. 14(3):382-384.

De Zwart LL, Vermeulen NP, Hermanns RC et al. (1999): Urinary excretion of biomarkers for radical- induced damage in rats treated with NDMA or diquat and the effects of calcium carbimide co-administration. Chem. Biol. Interact. 117(2):151-172.

Eaton DL and Klaassen CD (2001): Principles of toxicology. In: Casarett and Doull's Toxicology The Basic Science of Poisons, Klaassen CD, (ed), $6^{\text {th }}$ ed., McGraw-Hill, New York, pp. 1-34.

Gella FJ, Olivella T, Cruz Pastor M et al. (1985): A simple procedure for the routine determination of aspartate aminotransferase and alanine aminotransferase with pyridoxal phosphate. Clinica. Chimica. Acta. 153(3):241-247

Gil M, Tornas FA, Hess-Pierce B et al. (2000): Antioxidant activity of pomegranate juice and its relationship with phenolic Composition and processing. J. Agric. Food Chem. 48: 4581- 4589.

Goldberg DM and Spooner RJ (1983): Method for the determination of glutathione reductase. Methods of Enzymatic Analysis. 3(3):258-265.

Grant GH (1987): Amino acids and proteins: Fundamentals of clinical chemistry, $3^{\text {rd }}$ ed., WB Saunders, Philadelphia PA, pp.328-329.

Hammond AH and Fry JR (1999): Effect of cyanamide on toxicity and glutathione depletion in rat hepatocyte cultures: differences between two dichloropropanol isomers. Chem. Biol. Interact. 122 (2):107-115.

Hemmati AA, Rezaie A and Darabpour P (2013): Preventive effects of pomegranate seed extract on bleomycin-induced pulmonary fibrosis in rat. Jundishapur. J. Nat. Pharm. Prod. 8(2): 76-80.

Huang W, Dobberfuhl A and Filipppopoulos T (2005): Transcriptional up-regulation and activation of initiating caspases in experimental glaucoma. Am. J. Pathol. 167:673-681.

Keter LK and Mutiso PC (2012): Ethnobotanical studies of medicinal plants used by traditonal health practitioners in the management of diabetes in Lower Eastern Province, Kenya. J. Ethnopharmacol. 139:74-80.

Khan N, Syed DN, Pal HC et al. (2012): Pomegranate fruit extract inhibits UVB-induced inflammation and proliferation by modulating NF- $\kappa B$ and MAPK signaling pathways in mouse skin. Photochem. Photobiol. 88 (5):1126-1134.

King EJ and Armstrong AR (1934): Determination of serum and bile phosphatase activity. Can. Med. Associ. J. 31: 56-63.

Koppaka V, Thompson DC, Chen Y et al. (2012): Aldehyde dehydrogenase inhibitors: a comprehensive review of the pharmacology, mechanism of action, substrate specificity, 
and clinical application. Pharmacol. Rev. 64 (3):520-539.

Leung P, Moore TB, Miller C et al. (1993): Hydrogen cyanamide risk characterization document. Department of pesticide regulation California Environmental Protection Agency. Available from:

http://www.cdpr.ca.gov/docs/risk/rcd/hydro_c ya.pdf.

Lowry OH, Rosebrough NJ, Farr AL and Randall RJ (1951): Protein measurement with the FolinPhenol reagent. J. Biol. Chem. 193:265-275.

Manoilov S, Sedykh N, Firsova V et al. (1996): Effect of the catalase inhibitor 3-amino-1,2,4-triazole on oxidation-phosphorylation coupling and the state of the mitochondrial adenosine system in the liver of albino rats. Bull. Exp. Biol. Med. 121(6):576-578.

Meister RT (1994): Farm Chemicals Handbook'94. Meister Publishing Company, Willoughby OH USA.

Mukherjee S, Ghosh S, Choudhury S et al. (2013): Pomegranate reverses methotrexate-induced oxidative stress and apoptosis in hepatocytes by modulating Nrf2-NF- $\mathrm{B}$ pathways. J. Nutr. Biochem. 24 (12):2040-2050.

National Research Council (NRC) (1996): Guide for the care and use of laboratory animals. National Academy Press. Washington, D.C.

Ohkawa H, Ohishi N and Yagi K (1979): Assay for lipid peroxidation in animal tissues by thiobarbituric acid reaction. Anal. Biochem. 95(2):351-358.

Olaleye MT and Rocha BT (2008): Acetaminopheninduced liver damage in mice: effects of some medicinal plants on the oxidative defense system. Exp. Toxicol. Pathol. 59: 319-327.

Parmar HS and Kar A (2007): Protective role of Citrus sinensis, Musa paradisiacal, and punicagranatum peels against diet-induced atherosclerosis and thyroid dysfunctions in rats. Nutr. Res. 27: 710-718.

Reddy BU, Mullick R, Kumar A et al. (2014): Small molecule inhibitors of HCV replication from pomegranate. Sci. Rep. 4: 5411.
Rosen HR and Keeffe HR (2000): Evaluation of abnormal liver enzymes, use of liver test and the serology of viral hepatitis. In: Liver disease diagnosis and management. Bacon BR and Bisceglie AM (eds), Churchill Livingstone, New York. pp. 24-35.

Saxena B and Sharma S (2015): Food color induced hepatotoxicity in Swiss albino rats. Rattusnorvegicus. Toxicol. Int. 22 (1): 152-157.

Sen S, Chen S, Feng B et al. (2011): American ginseng (Panaxquinquefolius) prevents glucoseinduced oxidative stress and associated endothelial abnormalities. Phytomedicine. 18(3): 1110-1117.

Sheshadri SH, Sudhir U, Kumar S and Kempegowda P (2011): Dormex-hydrogencyanamide poisoning. J. Emerg. Trauma Shock. 4(3):435437.

Soltys D, Rudzinska-Langwald A, Kurek W et al. (2011): Cyanamide mode of action during inhibition of onion (Allium cepa L.) root growth involves disturbances in cell division and cytoskeleton formation. Planta. 234(3):609-621.

Takeo K (1987): Affinity electrophoresis. In: Advanced electrophoresis, Chrambach A, Dunn MJ and Radola BJ (eds), VCH Publisher, New York, pp. 229-279.

Wasser S and Tan CE (1999): Experimental models of hepatic fibrosis in the rat. Ann. Acad. Med. Singapore. 28:109-111.

Wei X, Fang R, Yang Y et al. (2015): Protective effects of extracts from Pomegranate peels and seeds on liver fibrosis induced by carbon tetrachloride in rats. BMC Complement. Altern. Med. 15: 389.

World Health Rankings (2014): Egypt: liver disease. Retrieved from (http://www.worldlifeexpectancy.com/egyptliver-disease, accessed on 13/9/2017).

Yeragi SG, Rana AM and Koli VA (2003): Effect of pesticides on protein metabolism of mudskipper Boleophthalmus Dussumieri. J. Ecotoxicol. Environ. Monit. 13(2):211-214. 
الملخص العربي

التسمم الكبدى بالسياناميد في ذكور الجرذان البيضاء البالغه والدور الوقائي العتمل لمستخلص بذور الرمان

\section{نعيمة محمود الحصرى و دعاء محمد الغرباوى ا و أميرة كسابץ و رحاب الغرباوى س}

المقدمه: يحتوي الدورميكس على المادة الفعالة "سياناميد"والتى تستخدم كسماد زراعي. ثمار الرمان تحتوي على العديد من البوليفينول التي تحمى الخلايا الطبيعية من عوامل الاكسدة.

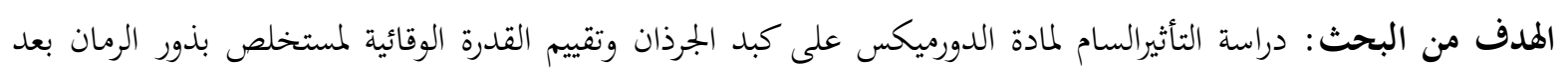
تناوله عن طريق الفم لمدة r أشهر.

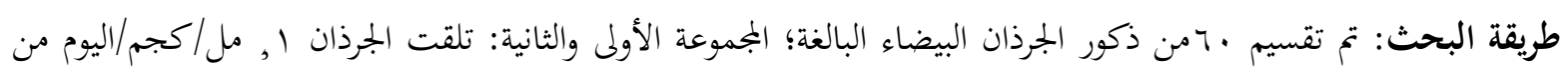

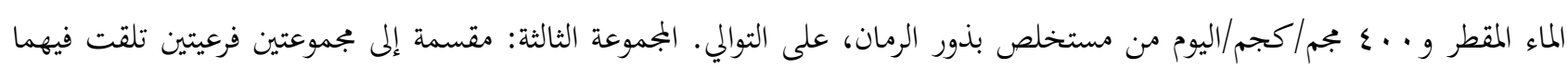

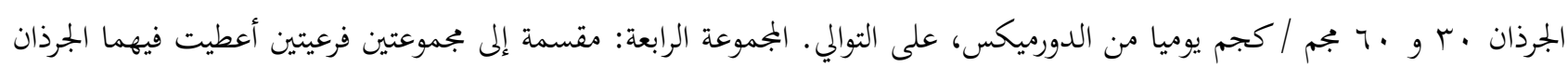
نفس الجرعة من الدورميكس بالإضافة إلى مستخلص بذور الرمان. و قد تم تحديد وزئ وزن الجسم والكبد، انزيمات الكبد في الدم، البيليروبين

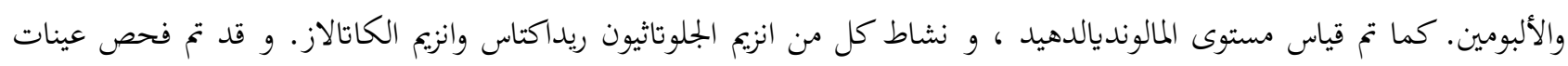

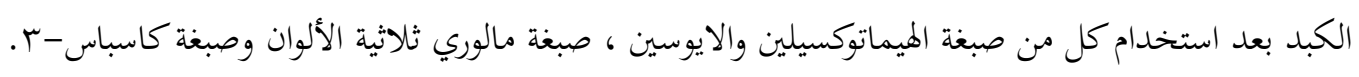

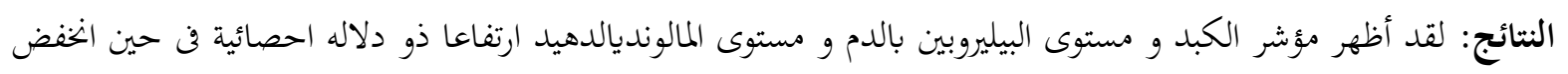
مستوى كل من الألبومين، الجلوتاثيون ريداكتاس، والكاتالاز بشكل ملحوظ في جرذان المجموعات التجريبية مقارنة بالمجموعة الضابطة.

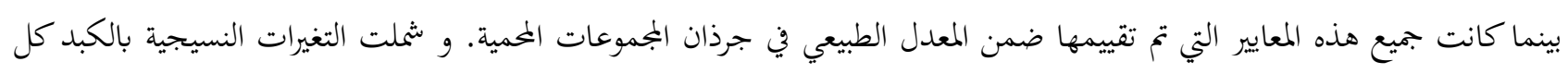

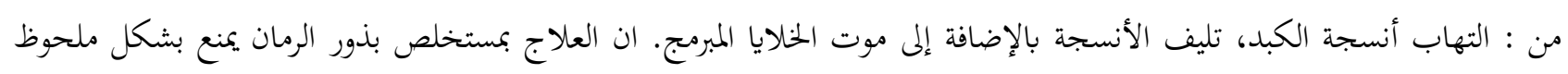

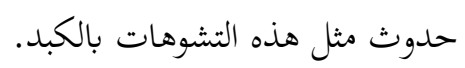

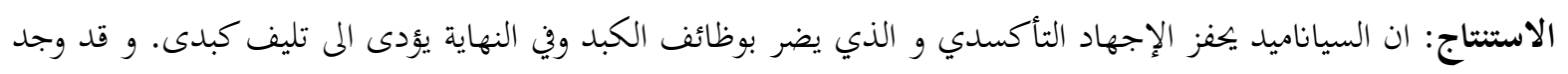
ان هذه الآثار السامة للسياناميد مرتبطة بالجرعة. بينما يمتلك مستخلص بذور الرمان القدرة على حماية الكبد من هذه التأثيرات السامة

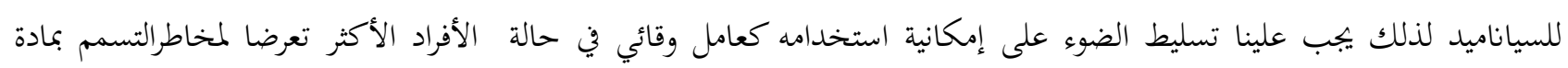

